\title{
The Comparative Historical Study of "Malin Deman and Puti Bungsu" Legend from Indonesia with "Niu Lang and Zhi Nu" from China
}

\author{
Ninawati Syahrul ${ }^{1}$, Sastri Sunarti ${ }^{2}$, Purwaningsih $^{3}$, Suryami $^{4}$ \\ \{ninawatisyahrul.bahasa@gmail.com ${ }^{1}$, sastri.sunarti@gmail.com², dianpurwaningsih@gmail.com ${ }^{3}$, \\ mimisuryami@yahoo.co.id ${ }^{4}$ \} \\ The Agency for Language Development and Cultivation \\ Ministry of Education, Culture, Research, and Technology of Republic of Indonesia \\ Jalan Daksinapati Barat IV, Rawamangun, Jakarta Timur
}

\begin{abstract}
This study is conducted by using a comparative historical analysis of two legends, entitled "Malin Deman and Puti Bungsu" from Indonesia (West Sumatra) and "Niu Lang and $\mathrm{Zhi} \mathrm{Nu}^{\prime}$ from China. It uses the Finnish comparative literary approach with the motifs method. The results of this study signify that four motifs described the pattern of Indonesian-Chinese literary and cultural kinship. The four motifs were (1) the motif about women and family, (2) the motif about color, (3) the motif about numbers, and (4) the motif about animals. Those motifs indicate a cultural connection between the two nations, Indonesia and China, combined as a characteristic of the Austronesian cultural region.
\end{abstract}

Keywords: Legend; Culture; Comparative; Motifs

\section{Introduction}

Folklore is a story of the past that characterizes every nation and describes various cultures and historical aspects. According to Djamaris [1], folklore is a collection of stories that live among all community levels and develop from generation to generation. In other words, folklore belongs to the community, not to the individual. As a genre of oral folklore, it is an element of collective culture. Therefore, people traditionally spread and pass it down from generation to generation in different versions [2]. The current reality depicts that people have abandoned folklore because modern society considers it irrelevant to their lifestyle and needs. Furthermore, it indicates the young generation's lack of interest in knowing culture through folklore[3]. One of the old literary genres, the story of consolation, served to comfort the heartbroken. Society passes this kind of story orally from one generation to the younger generation [4]. One example of a consolation story is "Malin Deman and Puti Bungsu," which conveyed an angel and a human marriage. That marriage occurred when a human and angel met in a forest. Malin Deman, who became the main character, met Puti Bungsu with his six siblings bathing in a lake. Luckless fate approached Puti Bungsu because Malin Deman kept her clothes, so she had to marry him. From their marriage, Malin Deman and Puti Bungsu had 
a child named Malin Duano. They lived happily like other families. However, the happiness ended when Puti Bungsu found her clothes. Then, Puti Bungsu preferred to return to heaven and left her husband because the earth was not her home [5].

The plot and theme of the story "Malin Deman and Puti Bungsu" was also found in the Chinese folklore "Niu Lang and Zhi Nu." The story's characters were a shepherd named Niu Lang, and a weaver, Zhi Nu. Niu Lang stole Zhi Nu's scarf while bathing in the river. In the end, Zhi Nu married Niu Lang. Fate came the other way around; the Heaven Emperor and the Fairy Goddess broke their relationship because humans and god were not meant to be together. On the seventh day of the seventh month of the Chinese calendar, the two of them met once a year at the bridge made by "magpies" [6].

Both stories exposed the similarities and differences of literary and cultural kinship patterns in terms of motifs. For example, there were motifs about women and families, motifs about numbers, motifs about color, and motifs about animals. However, in general, we can say that both were the same legend, but the story's origin was different, one from Indonesia and the other from China. In Indonesia and some various countries, especially Asia, similar stories were also widely known, although with different titles. For example, in Vietnam, there was a legend of "Lang and Chuc Nu," in the Philippines, it was entitled "Seven Young Sky Women," which was told by Richard Dorson in the book folktales "Told Around the World." In Japan, the story was famous as "Tanabata, Kyun-wo and Chik-nyo," and in Europe, "Swan Maiden."

A comparative historical study of folklore from various regions could reveal the kinship patterns and the spread of literature and culture among different ethnic groups. In addition, culture can be sufficient to help the challenges and efforts to promote their rights represent [7]. This research used a comparative historical analysis of two legends from two different countries, the legend of "Malin Deman and Puti Bungsu" from Indonesia (West Sumatra) and the Chinese legend, "Niu Lang and Zhi Nu".

\section{Methodology}

This study uses the Finnish comparative literary approach with the motifs method. According to Taum, the Finnish comparative literary approach is carried out by collecting, classifying, and compiling thousands of folk tales from around the world in such a way as to allow comparison and historical tracing of each folklore [8]. For folklore, this approach uses the story motifs as one of its essential criteria. Motifs are defined as the smallest value in a story that has a substantial value in tradition. Based on these criteria, motifs can be applied universally to folklore. Motifs are a narratives element. The motifs of folklore are prominent and unusual [9]. There are various motifs of folklore, among others as follows.

(1) The motifs are in the form of objects, such as wills, magic brooms, magic lamps, roses, clay, and celestial objects. The motifs in the story of the origin of humans, for example, humans come from clay, humans come from eagle eggs, and humans come from certain types of trees. They are related to belief/religion, fauna, and totem flora. (2) The motifs are in the form of extraordinary animals, such as flying horses, stealth crocodiles, human-headed lions, giants, talking animals, phoenixes, dragons, and roosters. (3) The motifs are in the form of concepts, such as a prohibition or taboo. For example, there are concepts that pregnant women should not eat twin bananas; after traditional circumcision (siphon), a man must go through a sex ritual with three women who are not his wife; people who are considered unlucky must perform a ritual; girls are not allowed to eat in front of the door; prohibition to cut certain trees in the forest. There are also some ceremonies to refuse the bad luck, as the clean village rituals 
and sea rituals by fisherman communities.(4) The motifs are in the form of action, such as the test of agility, drinking alcohol, meeting at the mountain, coming down from the mountain, disguised as the poor, acting selfish, performing ascetic acts, passing through the supernatural, fighting with giants. (5) The motifs are in the form of deception of a character (as a giant or an animal). There are many extraordinary animal motifs in Indonesia, such as a story about a deer and giants who can swallow or deceive humans. (6) The motifs that describe certain types of people, for example, the brilliant ones, such as Abu Nawas, the Pandir, and the Kabayan characters who constantly suffer from bad luck; the sage figures as King Solomon; heroic figures as Si Pitung, and sailor master such as Hang Tuah.

Stith Thompson (1885-1976) has compiled books in six volumes that contains various motifs and indexes of folklore around the world, entitled the Folk Literature Motifs Index: Classification of Narrative Elements in Folklore, Ballads, Myths, Fables, Medieval Romance, Example, Fabliaux, Jest-Books, and Local Legends [10]. We will find the uniqueness of a story or the only variant of folklore that exists in the world from Thompson's book. Furthermore, the book contains a catalogue of motifs that can be applied universally to folklore. Based on this classification, the life history of a folktale can be traced by comparing as many variants of stories with the same motifs as possible. The Finnish comparative literary scholar, based in Helsinki, is the center for worldwide researchers organization called The Historic-Geographical Method. The essential principles and results of their research have recorded in Thompson's book entitled The Folktale (Taum). Thompson in Georges the motif inherent in the collection of frequent tool stories, pioneering folklore pays attention to recurring characters, settings, incidents and events that storytellers continue to use and therefore appear to be the material from which stories are made [11]. William Bascom conducted folklore research in Africa by observing (1) the social context of folklore), (2) the relational folklore and culture, and (3) the function of folklore [12].

The method used in this study is a comparative descriptive method. The descriptive method examines the status of a group of people, objects, conditions, the system of thought, or the class of events in the present [13]. Descriptive research aims to make a systematic, factual, and accurate description of the facts, behavior, and relationships between the phenomena that are being investigated. According to Ratna, in research, a comparative descriptive combined method can be used by describing and comparing [14]. This study used the comparative descriptive method to compare motifs and history of the story "Malin Deman and Putri Bungsu" and "Niu Lang and Zhi Nu" from China. The sample, as well as the object of research, are the stories "Malin Deman and Putri Bungsu" (Navis, A.A. 2001) and "Niu Lang and Zhi Nu" (Hingoan Gunawan and Martini, 2000).

\section{Result and Disscussion}

\subsection{Women and Family Motifs and Comparative Cultural Values}

In Confucius's view, the entire ethical system of traditional Chinese society is centered on the family. The existing family system is hierarchical and authoritarian. Thus, the status and level of each person are highly dependent on the status of birth and marriage. A husband in a family is the center of power which is in charge of overseeing and controlling the family's wealth. The legend of "Niu Lang and $\mathrm{Zhi} \mathrm{Nu"} \mathrm{reflects} \mathrm{the} \mathrm{culture} \mathrm{of} \mathrm{Chinese} \mathrm{women} \mathrm{and}$ families. This culture, for example, can be seen through Zhi Nu's attitude when he first met Niulang. 
"Hmm, he seems like a nice guy. Diligent, honest and trustworthy", Zhi Nu decides to marry Niu Lang. Niu Lang and Zhi Nu live happily in their simple house. (Niu Lang and Zhi $\mathrm{Nu}, 2000: 6--7)$.

The quote shows that from the first time Zhi Nu saw Niu Lang, Zhi Nu immediately fell in love with him. Therefore, she confidently agreed to marry Niu Lang. They both love each other. After they got married, even though $\mathrm{Zhi} \mathrm{Nu}$ didn't need to weave anymore, it didn't make her standstill. Zhi $\mathrm{Nu}$ is still weaving. She even took the initiative to continue weaving to support the family income. Zhi $\mathrm{Nu}$ is a nymph who is the granddaughter of the Heaven Emperor and the step-granddaughter of the Fairy Goddess, and she is an expert in weaving beautiful patterns and good at telling stories. When humans see the sky is bright and there are seven colors of the rainbow, the Chinese believe this natural phenomenon has come from the nymph's skilled hands. She also constantly encouraged Niu Lang, so Zhi Nu could have done her duty as a good wife. After marriage, Zhi Nu must submit and maintain good relations with her husband. As a wife, she does all the household chores [15].

The inferior position of women is reaffirmed by Confucius's teaching, which is a rational justification for this social system [16]. In Confucius's view, the relationship between husband and wife must be based on excellent and commendable qualities. A husband must respect his wife. On the other hand, a good wife must be submissive and obedient to her husband's orders. A bad wife is a wife who disobeys her husband's orders. Being submissive to virtue is considered the highest work of women. Being a wise mother and a good wife is the main goal in a woman's life. Women must also be able to maintain their purity.

There are several other essential teachings related to the position of women in China, for example, the three principles of obedience and the seven basic crimes that are used as life guidelines (Myra Sidharta). In the three principles of obedience, men have greater rights than women. First, as a child, a woman must obey her father; then, she must submit to her husband as a married woman. Finally, as a woman her husband has abandoned, she must abide by her son [17]. Thus, women are never independent because there will always be men whom they must obey. In Chinese cosmology, women have always been looked down upon and subservient, just like the earth. The effort to civilize women has resulted in production and reproduction processes related to the relationship between men and women [18].

In human life, women are only seen in the family context, while men are seen in a more comprehensive socio-political relationship outside the household [19]. This relationship shows that the rights of men are greater than women's. The Zhi Nu and Niu Lang families spend their days warmly. Another obligation imposed on a wife is to bear children to maintain the family lineage, quoted as follows. They have a cute and healthy son and daughter. When night fell, Zhi Nu and Niu Lang often sat outside with their two children while looking at the stars in the sky. Zhi Nu tells her children about life at the Heaven Kingdom and her origins (Niu Lang and $\mathrm{Zhi} \mathrm{Nu}$ ). The quote proves that the presence of a boy in this legend reflects the culture about continuing heredity. According to Meng $\mathrm{Zi}$, regarding the culture of continuing the descendants, by giving birth to a son, there is a hope that the wife will get good attendance from her husband's family (Myra Sidharta).

In ancient Chinese society, the birth of a baby girl was never greeted with joy. This thing is related to the family lineage prevailing in China. Only sons can continue the family name. Without sons, the family lineage ended, and it is the greatest treason for the ancestors. Therefore, girls are only considered people who ride in the family until it's time for marriage. 
One of the literary works defined by Confucius, entitled the Shih Ching (The book of Poetry Collections), was written as follows.

\author{
Sons shall be born to him \\ They will be put to sleep on couches \\ They will be clothed in robes \\ They will have sceptres to play with \\ Their cry will be loud \\ They will be (hereafter) resplendent with red knee-covers \\ The future king, The princes of the land \\ Daughter shall be born to him \\ They will be put to sleep on the ground \\ They will be clothed with wrappers \\ They will have tiles to play with \\ It will be theirs neither to do wrong nor to do good \\ Only about the spirits and the food will they have to think \\ And to cause no sorrow to their parents \\ (Myra Sidharta, 2000:106).
}

The poem clearly shows how ancient Chinese society viewed women as lower than men. For example, the treatment of boys is very different from the treatment of girls. The poem also clearly mentions that the rights of men are higher than the rights of women. Meanwhile, women are required to be good wives in the family. Another view is that structure of society is always based on relationships that are rooted in the gender hierarchy. Gender determines social status, life experiences, physical and psychological conditions and values (Jagger in Permana) [20].

The fundamental Confucian view that women are not the same as men is very decisive. The role of women is limited to producing sons as heirs to her husband's family and taking care of all household affairs. The role is, in fact, more complex than the role of men, but their achievements are still limited to family relations. For them, the family is the basis of larger social relationships, so that the role of women becomes essential and must fulfill this role (Myra Sidharta). The inequality of rights between men and women in ancient Chinese society concerning married life is also evident in the seven basic crimes used as grounds for divorcing a wife. The seven things are disobedience to the husband's family, failure to produce male offspring, adultery, suffering from an incurable disease, jealousy, and talkative (Sun Ai Lee Park, 1995).

Some Chinese people have the assumption that the point of perfection or complete conditions are if there is a pair of men and women united. Therefore, the hidden meaning in the phrase "a son and a daughter" in the legend "Niu Lang and Zhi Nu" emphasizes that the Niu Lang family spends their days full of happiness and warmth. Finally, even though Niu Lang has returned his wife's clothes, Zhi Nu is willing to leave his life in heaven and choose to live on earth. When the Fairy Goddess brought $\mathrm{Zhi} \mathrm{Nu}$ back to heaven. Zhi Nu still insists on staying in the human world. Even though $\mathrm{Zhi} \mathrm{Nu}$ has to weave clothes and do household chores diligently, just like other women on earth, Zhi Nu wholeheartedly serves her husband.

In terms of eastern or West Sumatran culture and customs, a married woman who becomes a wife will take care of the children or the family, including taking care of her husband's food and clothing problems. Since prehistory, cooking and staying at home have been women's 
business, while men's business is hunting and working. In the process of determining their life path, women must think and be responsible for their choices. By nature, women have the task of giving birth to children, and culturally they have the task of raising children. It means that giving birth to children is God's will, while the culture of raising children, moreover submitting to men, is a choice, not a destiny.

In West Sumatra convention, Hakymi Dt. Rajo Penghulu (1991) classifies women into three categories, namely parampuan, simarewan, and mambang tali awang. Parampuan refers to women who have good character, trust in God, are polite and respect others. Simarewan relates to women who do not have a stand and do not have character. Mambang tali awan is an arrogant woman, has no respect, and is inconsiderate. For women, by understanding their role and position in Minangkabau customs in-depth, they can undoubtedly motivate themselves and provide inspiration to carry out their roles as West Sumatra women.

The legend of "Malin Deman and Puti Bungsu" can reflect the culture of women and families of Indonesian society as seen from the actions of Puti Bungsu. She is very skilled at doing household chores. Every day she served very delicious food. In addition, she also made her house very clean, bright, and luminous. Puti Bungsu's attitude can reflect the Indonesian society culture, especially the women of West Sumatra, regarding the role between women and families. This legend tells that although Puti Bungsu is an angel from heaven's kingdom, she still shows West Sumatra culture. For example, she is cooking and managing household chores. In addition, Puti Bungsu gave birth to Malin Duano, who was very beloved to his parents. Based on the analysis, both the legends of "Niu Lang and Zhi Nu" and "Malin Deman and Puti Bungsu" reflect women and families' culture.

When viewed from the wife's point of view, after getting married, the two of them ( $\mathrm{Zhi} \mathrm{Nu}$ and the youngest daughter) both worked hard to do household chores and were willing to sacrifice for the sake of their respective families. Moreover, their presence in the human world brings happiness and pride to their husbands. The Chinese state since ancient times until now, emphasizes the mindset of zhòng nán qīng nü (the position of men is more highly respected than the position of women)". The Chinese have always assumed that men occupy a higher position than women because they can carry on the clan name.

Therefore, women who become wives in a family must give birth to sons. In the legend, we can also find that $\mathrm{Zhi} \mathrm{Nu}$ gave birth to a son and daughter to Niu Lang. However, The Chinese culture is different from Indonesian culture; men and women have the same equality. Indonesian society does not require a woman to give birth to a son like in China. This can be seen from the legend "Malin Deman and Putri Bungsu," even though Puti Bungsu gave birth to a son, Malin Deman was thrilled. It is evidence of the cultural differences between China and Indonesia. The truth values of the roles of men and women in the two stories are embedded in one system at a certain time. Kleden, mentions that truth is about what is right or wrong, present in all groups of people throughout the ages. In certain cultures, the question of truth has been developed systematic as a separate intellectual endeavor, in others it is lived only in everyday life and is expressed in speech and deed [21].

\subsection{Color Motifs and Comparative Cultural Values}

For more than 2.000 years, the Chinese have used brilliant colors. Today in modern China, red is the most popular color. However, contrary to popular belief, ancient people did not pay special attention to red color. Traditional Chinese society teaches five elements, namely water, fire, wood, metal, and earth, which are in order of black, red, blue, green, white, and yellow. The ancient Chinese believed that the five elements formed everything in nature. Five 
thousand years ago, during the reign of Huang Di (known as the Yellow Emperor), people truly worshiped the yellow color. From the period forward, Chinese emperors used the Five Element Theory to choose colors through the Shang, Tang, Zhou, and Qin dynasties.

People understand that "color comes naturally, while black and white comes first," they gradually form a connection between color and the principles of the five elements, guided by the natural movements of the heaven and the Tao. People choose clothing, food, transportation, and housing according to the changing nature from spring to summer and fall, then to winter. The traditional Chinese regards black, red, and blue-green, white and yellow as the standard colors. Color in Chinese culture refers to various colors considered auspicious or unfavorable - the Chinese character for color (yan se). In ancient Chinese, the character more accurately meant the color on the face. During the Tang Dynasty, yan se began to refer to all colors. The Chinese idiom "wu (five) yan liu (six) se," which is used to describe many colors, can also denote colors in general.

The red color, corresponding to fire, symbolizes good luck and joy. The Chinese, both ancient and modern, appreciated the red color. Red is the color during Chinese New Year, holidays, and family gatherings. A red envelope is a gift given in Chinese society during a holiday or special day. The red color is prohibited at funerals because it is a traditional color symbolic of happiness. From ancient times until now, Chinese people have paid great attention to color culture. For example, the red color, which presents joy, was considered a precious color worn by the nobility. The culture of this color can be seen in the dress and celebration of ancient Chinese society. It turns out that this color culture is still embedded in the legend of "Niu Lang and Zhi Nu."

"Niu Lang, my best friend, said Ox. Do you know? Tomorrow at sunset Zhi Nu and the nymphs from the sky castle would bathe in the river behind the mountain. If you take thin red clothes, the beautiful $\mathrm{Zhi} \mathrm{Nu}$ will be your wife" (Niu Lang and Zhi Nu, 2000: 4).

When creating the legend "Niu Lang and $\mathrm{Zhi} \mathrm{Nu,"} \mathrm{the} \mathrm{Chinese} \mathrm{also} \mathrm{pay} \mathrm{great} \mathrm{attention} \mathrm{to}$ color. It turns out that they did not choose the color in the tale at will, but because it has its meaning. They deliberately chose the "red" color as Zhi Nu's clothes to describe the Zhi Nu situation deeply. This legend says seven nymphs were bathing in the river, but the old cow chose the nymph who wore red clothes, namely $\mathrm{Zhi} \mathrm{Nu}$. This is because they firmly believe that the red color can bring good luck.

Red is the color of fire and blood, the blood of life, the blood of a slaughtered person, or menstruation. In addition, red is often associated with energy, war, strength, strong will, desire, and love. It is related to emotions, so that it is synonymous with shame and anger. From a psychological point of view, red can increase the human body's metabolism and improve the rhythm of breathing and blood pressure. The red color is important for Chinese culture, widely absorbed and assimilated into the local culture. In Chinese culture, red represents the element of fire or huo, which symbolizes hope and happiness. [22].

If the "angel in red clothes" married Niu Lang, it would mean that Niu Lang's life would be happier. Therefore, Niu Lang will pass the day with good luck, and he can resolve all problems. Thus, this legend reflects the color culture in Chinese society. In terms of color culture, Indonesian is very different from Chinese. In the legend of "Malin Deman and Puti Bungsu, it is stated that the angel has white Sonsong Barat clothes. For the Minangkabau people, white is the primary color represented by the four colors of greatness or marawa. The white color is a symbol of purity and decency (alua and patuik). 
Malin Deman knew that they would not be able to return to heaven without those clothes. He also knew that the angel who had lost her clothes would continue to search following the flow of the lake water because she thought the flow washed her clothes away. Therefore, Malin Deman waited for the lost Goddess at the first bottom of the lake's water flow. Malin Deman's suspicions were correct. While crying, Puti Bungsu asked. "Hey, young man, did you see my clothes that wash away? Malin Deman claimed not to have seen it, but he asked, "Who are you at this time of night still in the forest." Puti Bungsu tells who she is and will not return to heaven without the Sonsong Barat Putih clothes. ("Malin Deman and Puti Youngest," 2001: 60)

Alua means 'groove' or 'procedure,' which in conversation also means 'to deceive.' Patuik means 'appropriate', 'convenient, or 'not'. So, alua jo patuik is a proper or not proper procedure. Before deciding something, we must take alua or procedures first. Therefore, we must be careful and thorough to consider all problems so that we can resolve all problems as well as possible. According to ancient stories, if a rainbow appears, it must be associated with angels bathing down from heaven using their scarf. Each angel uses a scarf with a different color, like the color of the rainbow. When the angel descends and ascends to heaven, the color of the scarf forms a beautiful rainbow color. This story turns out to do with the legendary story "Malin Deman and Puti Bungsu". From this explanation, we can conclude that Chinese culture always has respected color, as reflected in the legend of "Niu Lang and Zhi Nu." On the other hand, in Indonesian culture, there are still views about the meaning of color as expressed by the legend "Malin Deman and Puti Bungsu," specifically the white color of the Sonsong Barat clothes taken by Malin Deman. These two things are the common points in the legends of the two countries

\subsection{Number Motifs and Comparative Cultural Values}

On the night of the seventh day of the seventh month of the Chinese calendar, the cowherd Niu Lang and the heaven nymph will meet in the Milky Way galaxy across a bridge formed by

a magpie. They only meet once a year. This story has long circulated in various circles of Chinese society. The number seven is associated with the big dipper (big dipper, north-star, bai dou). This star seen in the sky is always in the same formation and rotates from time to time, with the two stars at the ends pointing in the direction of the star Polaris (northern star). The number seven also represents good things, such as qi which means 'to start' or 'to rise.' There is also the Qixi Festival, better known as Valentine's Day in China, which falls on the seventh day of the seventh month of the Chinese calendar. The number seven is also often referred to as luck, lucky seven.

Finally, Niu Lang and Zhi $\mathrm{Nu}$ and their two children were able to meet on the bridge. The Fairy Goddess couldn't do anything. Every night of July 7th (seventh), Niu Lang and Zhi Nu and their children met together. Their feelings were mixed between sadness and happiness (Niu Lang and Zhi NU, 2008:12).

The legend "Niu Lang and Zhi Nu" also uses the number seven to tell of a nymph who came down to the human world to bathe. The number seven is considered a holy and sacred number. The number seven in the I-Ching Trigram was discovered by Fu Xi more than 4,000 years ago. It is Dui (pronounced Tui) that represents the youngest daughter. In China, seven is 
believed to be a lucky number because seven in Chinese is similar to the pronunciation of the words rise and live. The number seven is also believed to be a symbol of togetherness. Therefore, seven is seen as a good omen, a sign of the universe that combines heaven, which is symbolized by the number three and earth, represented by the number four. We should note that the number seven has also been used in human culture and history for a long time.

Odd numbers have a myth in the nation's life and are believed to mean better than even numbers. In Chinese culture, almost all goods inevitably have odd numbers. They also add this odd number in motorcycle license plates, shop names, restaurant names, or place names.

This Chinese people's view makes them use the number seven to describe the occultation of the seven nymphs who took a bath in "Niu Lang and Zhi Nu." Besides being considered holy or sacred, this number is also believed to be the number that can bring fortune. The number seven in this legend also explains that the angels who bathe in the river can all bring luck and fortune. Therefore, the number seven in the legend "Niu Lang and $\mathrm{Zhi} \mathrm{Nu}$ " reflects the number of cultures in China. "They have a cute and healthy daughter and son" (Niu Lang and Zhi Nu, 2000:6--7).

The quote shows that Niu Lang has two children. It becomes a reflection of the culture of continuing heredity and the culture of numbers. The ancient Chinese people preferred the number two, which means 'double' or 'twin.' In most cases, the number two is a lucky number; all in pairs can bring luck and fortune. They also like things in pairs, as seen in the legend "Niu Lang and Zhi Nu" which symbolizes good luck and happiness for the Niu Lang and Zhi $\mathrm{Nu}$ families. The legend of "Malin Demand and Putri Bungsu" also alludes to the culture of numbers in the people of West Sumatra, Indonesia.

A young man named Malin Deman. Out of his house went fishing in the river. From downstream to upstream of the lake, Malin can not find a single fish. Finally, when he was about to return home, he heard the sound of people chatting. He traced the direction of the voice. Then, he saw seven goddesses bathing and swimming in the lake. Captivated by their beauty, his heart locked at one of the Goddesses. He stole her clothes which were hanging from the branch of a tree. He hid it under his clothes ("Malin Deman and Puti Bungsu," 2001: 60).

Malin Deman saw seven clothes scattered on the ground; he took one of them, it turned out that the clothes he assumed belonged to Puti Bungsu. The legend of "Malin Deman and Puti Bungsu" takes the metaphor of a woman taking a bath. According to Oppenheimer, angels bathing in the lake is a metaphor for the moon's appearance, whose light reflects on the surface of the water. The metaphor of the moon is also reinforced by the number of nymphs, which is usually seven, which represents the Pleiades constellation which marks the growing season. [23]. The legend "Malin Deman and Puti Bungsu" mentions the number seven as a revered and magical number. The number seven in these seven nymphs symbolizes the world outside the earth and explains the nymphs' mystiques.

Puti Bungsu gave birth to a son, then named him Sutan Duano. In addition to the number seven, this legend also mentions the number one. According to John Afifi, Indonesian people believe that odd numbers are more mystical than even numbers. This view also has an impact on the legend of "Malin Deman and Putri Bungsu." The legend does not mention even numbers because the culture of the people believes that one is a good number. The situation or 
matter of giving birth to a son in the legend of "Malin Deman and Putri Bungsu" is also closely related to this culture [24]. In this legend, the birth of a boy and number "one" means the beginning of life - a new life (or the birth of a baby boy). The translation of the number "seven," both in China and Indonesia, has mystical or magical meanings. Both of these legends use the number "seven" to describe the mysterious aura of the seven nymphs. However, this legend also has a difference: China prefers to represent the number two, which means "pair," as opposed to Indonesia. It means that Indonesia and China both have numbers motifs in their culture. Indonesia uses number "one" and China uses number "two."

The Basandi Sarak Philosophy, Sarak Basandi Kitabullah, is one of the life philosophies held by the Minang community. Islam becomes the main foundation in their behavior system and their values of life. The number "seven" is also extraordinary in Islam. For numerology observers and Muslim intellectuals, every number holds a secret and mystery. Among the numbers that are very familiar to Islam is "seven." In the Encyclopedia of Miracles of the Qur'an and Hadith (Volume 10), the number seven has special features in addition to the number one [25]. There is an integral system in the Qur'an related to the number seven. The number seven is a number that testifies to the goodness of God. This natural system is based on the number seven because this number is often repeated systematically in the book of God. God is "witir" odd/single and adore the odd numbers. Some circles, including the scholars, say that this number indicates an odd number, as if "loved by God."

By observing the surrounding environment, the number seven becomes a clue to nature and life. First, the universe cannot be separated from the number seven. "Allah is He Who created seven heavens, and of the earth the like of them (seven ground levels). The Command continues to descend between them (heavens and below ground), that you may know that Allah has power over all things and that Allah indeed encompasses (surrounds) all things with (His) Knowledge." (QS ath-Thalaq: 12). God created nature by choosing the number seven to be the sum of the levels of heaven and earth. The explanation of the creation of the seven heavens is also explained in seven verses of the Qur'an. The first mention of the number seven in the Qur'an is in the Al-Baqarah verse 29.

"It is He who created for you all that is in the earth, then He turned to the heaven and fashioned it into seven heavens, and He has knowledge of all things".

Second, the Prophet often mentioned the number seven. Number seven has many features in the hadith of the Prophet. This number has an important position because the Apostle often repeats it. For example, when the Prophet spoke of major sins, he mentioned seven major sins. Likewise, when speaking of the torment on the last day, the Apostle said, increasing the torment up to seven times the size of the earth. Likewise, in terms of worship, the Apostle repeated the number seven in Surah Al-Fatihah as an obligatory letter to be read in prayer. In addition, God also commands that prostration use seven limbs. Third, the number of prophets. Many prophets and apostles often mention the number seven in their stories. Prophet Noah, for example, describes the creation of the seven layers of the sky. Prophet Yusuf often said the number seven in his dream interpretations. Two verses of God's word tell of the number seven in the story of the Prophet Yusuf (Surah Yusuf verses 43, and 46-48). Likewise, the torment that was inflicted on the Prophet Hud's people, the Ad.

And but Âd (nation) however (too) was destroyed by an extremely freezing, excessively blowing fierce storm. (Allah) assigned it (the storm) upon them seven nights and eight days continuously. (QS al- Haqqah ayat 6-7). 


\subsection{Animal motifs and Comparative Cultural Values}

The legend of "Niu Lang and Zhi Nu" used an old cow to help Niu Lang. The cow symbolizes strength associated with harvesting fertility, perseverance, patience, and enduring adversity. In addition, Ancient Chinese art also considered the animal to be auspicious, which had given the cow a reputation for granting wishes and a symbol of unique character or personality. Therefore, the Chinese used this animal to describe the use of the old cow in this legend in greater depth. The legend tells that this old cow always helped Niu Lang. Moreover, Niu Lang voluntarily used his skin to chase after Zhu Nu. It proves that the Chinese people use this animal culture to tell the nature of this old cow. Besides old cows, China also discusses other animals, the magpies.

The magpie is well known in Chinese culture to symbolize joy, luck, and romantic relationships. Their imagery is prevalent, and even these birds are connected with myths and stories about successful romantic relationships. Images that include a pair of magpies can be placed in the Kun (partnership) area of the Bagua Map to attract a happiness into people's lives. Niu Lang and Zhi Nu's love touched the hearts of tens of millions of magpies which later formed the Magpie Bridge to bring together Niu Lang and Zhi Nu. In the conflict resolution part, because this magpie felt sorry for Niu Lang and $\mathrm{Zhi} \mathrm{Nu}$, this bird made a bridge on both sides of the Milky Way to unite Niu Lang and Zhi Nu. This incident caused the Chinese to think that they were birds of happiness.

Regarding the animal motifs in Indonesian folkflore, they can also be found in the legend of Malin Deman and Puti Bungsu. But after the birth of their son, Sutan Duano, Malim Deman turned into a slacker. He no longer works in the fields; instead, he spends many days not coming home because he is busy cockfighting. The pattern thought inherent in society that considers cockfighting culture is a manifestation of human reason or behavior which course refers to the rationality values in persistence [26] Her husband's behavior made Puti Bungsu sad. She often cries. She misses her sisters in heaven. Puti Bungsu is very disappointed with Malin Deman's behavior, who did not want to change. In other words, Puti Bungsu's husband is no longer responsible for his wife and children. For his daily life, his wife works in the fields.

Who was not familiar with the game of rooster fighting or cockfighting? a famous traditional game among the society of the Archipelago, especially in West Sumatra. This game fights the rooster with spurs that are sometimes added or made of pointed metal. Cockfighting activities do not necessarily immediately become gambling activities depending on whether there is an element of betting or not, because there are people who fight cocks just for fun or even because of traditions that are passed down from generation to generation [27]. The game of cockfighting in the Archipelago is an entertaining game for the community and a story of life, both social, cultural, and political. According to Bourdieu, there are several types of social capital, namely economic, social, symbolic and cultural capital [28]. However, Malin Deman spent his time on cockfighting, not as a hobby but as gambling. Therefore, when people take gambling actions, they are already in a position that really hopes that fate will determine whether they win or lose in a gambling game [29].

We can learn many philosophies from the cockfighting game in West Sumatra. However, the primary reason why the Indonesian people, especially West Sumatra, play the cockfighting game as in this legend, as follows. According to Purwaningsih in his article entitled "Cockfighting in Southeast Asia: A Comparative Study of Indonesia, Malaysia and the Philippines" describes that cockfighting is a traditional game in Southeast Asia which is a lifestyle and social status of men [30]. 
a) Bold and honest

A rooster who sees another rooster around him will immediately approach the opposite rooster with a bold attitude. Sometimes that opposite rooster has certain advantages, such as a larger body. Therefore, he will knock the rooster without paying any attention to its capability. But, on the other hand, if he feels that the opposite rooster is not his match, he will immediately stop the fighting and directly run away after a few strokes of the fight. That is, the loser rooster honestly admits that he is not a worthy opponent for the champion. This attitude is maintained as long as it feels unable to compete against the champion. Therefore, he will dodge if he meets his enemy.

b) Knight's Attitude

Fighting is an instinct of the chicken. The rooster will fight with all its power and abilities to fight and defend its territory. The rooster that controls the area will fight it out to protect the area. Meanwhile, the newcomer will do the same thing: rally all its abilities to seize or control the area. After the fight, they get the winner, the rooster of the region's ruler or the newcomer. The winning rooster will crow with a loud voice calling for his victory, while the losing rooster will sportively admit defeat and run away from the winner.

c) Sportsmanship

What will the defeated rooster do in the fight for the territory? Withal to running away, the chicken will also voice its defeat with a "clack" sound! With sportsmanship and honesty, the losing rooster admits his defeat and runs away. The defeated rooster accepts his loss with a "cuck-cuck" sound and acknowledges the greatness of his enemy by running away. The winning rooster will crow and will not hunt the defeated rooster to death.

d) Protecting its partner

The fights between roosters are often due to fighting over a partner during the mating season. The winner will be the contested pair, and the loser will run away sportively to find another partner. What does the winning rooster do if it finds food when it is with its partner? It will not rush to eat the food alone, but it calls its partner to eat it first.

Those are some lessons or philosophies that we can learn from the fighting rooster and the fighting trademark. Of course, agreeing or disagreeing with the opinion is depends to each individual. However, this philosophy can be learned as a lesson. Based on the analysis between the two countries, there are still thoughts about animals culture. For example, legends in China use an old buffalo and a magpie to describe the legend's condition and use these animals in more depth. Similarly, Malin Deman and Puti Bungsu in Indonesia, which put a rooster in the tale.

The story's motif, with its variations, shows the similarities that become the common culture and the uniqueness that becomes the local color. The similarities and variations of the motifs occur because they come from the same or different sources, which are in the theory of origin known as monogenesis or polygenesis. Thus, the roots and extended distribution are what cause the variety of stories to emerge. From this diversity, we can draw and trace a common thread that shows the unity and diversity of various ethnic groups [31].

This study clearly shows the existence of cultural kinship between Indonesia and China, which is proven through the Austronesian cultural kinship. For example, the legend of the seven nymphs originally came from China, then spread to all areas of Austronesian culture through Formosa Island (Taiwan) [32]. However, due to a long history, there are also significant differences in symbols and cultural meanings. Therefore, based on these findings, we can identify similarities and cultural differences between the two ethnic groups/nations. 


\section{Conclusion}

Based on the description, it is clear that a pattern of literary and cultural kinship can be seen in the following four motifs. (1) Motifs about women and families. After getting married, Puti Bungsu and Zhi Nu worked hard at household chores, willing to sacrifice themselves for their families. The difference is that Chinese culture emphasizes the position of men being higher than women because they can carry on the surname. Therefore, women must give birth to sons. It is not emphasized in the cultural view of Indonesian society; the position of men and women is balanced. (2) Motifs about color. The legend of Niu Lang and Zhi Nu firmly upholds the "angel wearing a red dress" color motif. The tale of Malin Deman and Puti Bungsu also maintains the color motif "an angel who wears white Sonsong Barat".

(3) Motifs about numbers. Both of these legends use the number 7 (seven) to describe or reflect the mystical aura of the seven nymphs. In the two legends being compared, Chinese culture prefers even numbers, in contrast to Indonesian culture, which believes odd numbers are more magical. (4) Motifs about animals. Chinese culture uses old cows and magpies to describe the legendary conditions and uses of these animals. Similarly, the legend of Malin Deman and Puti Bungsu includes a rooster.

This study clearly shows the existence of cultural kinship between Indonesia and China, which is proven through the Austronesian cultural kinship. The legend of the seven nymphs originally came from China, then spread to all areas of Austronesian culture through Formosa Island (Taiwan). However, due to a long history, there are also significant differences in symbols and cultural meanings. We can identify similarities and cultural differences between the two ethnic groups/nations based on this study.

\section{References}

[1] E. Djamaris, Menggali Khasanah Sastra Melayu Klasik. Jakarta: Balai Pustaka., 1993.

[2] S. Endraswara, Folklor Nusantara. Yogyakarta: Penerbit Ombak., 2013.

[3] A. Humaeni, "Makna Kultural Mitos dalam Budaya Masyarakat Banten," Antropol. Indones., vol. 33, no. 3, p. 174, 2012.

[4] L. Y. Fang, Sejarah Kesusastraan Klasik. Jakarta: Yayasan Obor., 2011.

[5] A. A. Navis, Cerita Rakyat dari Sumatra Barat. Jakarta: Grasindo., 2001.

[6] Hingoan Gunawan dan Martini, Niulang dan Zhinu. Jakarta: PT Elex Media Komputindo., 2000.

[7] M. De la Cadena, "Indigenous Cosmopolitics in the Andes. Conceptual Reflections Beyond Politics," Cult. Anthropol., vol. 25(2), pp. 334--370, 2010.

[8] Y. Y. Taum, Studi Sastra Lisan: Sejarah, Teori, Metode dan Pendekatan Disertai Contoh Penerapannya. Yogyakarta: Lamalera, 2011.

[9] J. Danandjaja, Folklor Indonesia, Ilmu gosip, Dongeng, dan Lain-Lain. Jakarta: PT Pustaka Utama Grafiti., 2007.

[10] S. Thompson, Motif-index of folk-literature: a classification of narrative elements in folktales, ballads, myths, fables, mediaeval romances, exempla, fabliaux, jest-books, and local legends. Bloominton: Indiana University Press, 1966.

[11] R. A. Georges, "The Centrality in Folkloristics of Motif and Tale Type," Folk. Res., vol. 34, no. 3, pp. 203--208, 1997.

[12] W. Bascom, "Folklore Research in Africa," Am. Folk., vol. 77, no. 303, pp. 12--31, 1964, doi: https://doi.org/10.2307/536411. 
[13] N. Muhammad, Metode Penelitian. Jakarta: PT Ghalia Indonesia., 2003.

[14] N. K. Ratna, Teori, Metode dan Teknk Penelitian Sastra. Yogyakarta: Pustaka Pelajar., 2013.

[15] M. Sidharta, "Korban dan Pengorbanan Perempuan Etnis Cina," in Dalam I. Wibowo, Harga yang Harus Dibayar: Sketsa Pergulatan Etnis Cina di Indonesia, Jakarta: Gramedia Pustaka Utama dan Pusat Studi Cina., 2000.

[16] Y. L. Fung, Sejarah Ringkas Filsafat Cina: Sejak Confusius Sampai Han Fei Tzu. Yogyakarta: Liberty., 1990.

[17] Jung Chang, Angsa-angsa Liar: Tiga Putri Cina. Jakarta: Gramedia Pustaka Utama., 2005 .

[18] I. Abdullah, Dari Domestik ke Publik: Jalan Panjang Pencarian Identitas Perempuan, Sangkan Paran Gende. Yogyakarta: Pustaka Pelajar, 1997.

[19] S. A. L. Park, “"Konfusianisme dan Kekerasan terhadap Perempuan",” in Dalam Konfusianisme di Indonesia: Pergulatan Mencari Jati Diri., Yogyakarta: Pustaka Pelajar dan MATAKIN., 1995.

[20] R. Permana, "Konsep Budaya Kesejajaran Pria dan Wanita pada Masyarakat Baduy," Wacana, vol. 1, no. 2, pp. 248--260, 1999.

[21] P. B. Kleden, "The Truth in Relation A Lamaholot Understanding of Truth," Antropos, vol. 114, pp. 107-117, 2019.

[22] K. Allan, "The Connotations of English Colour Terms: Colour-Based X-phemisms," J. Pragmat., pp. 626--237, 2009.

[23] S. Oppenheimer, Eden in the East (Benua yang Tenggelam di Asia Tenggara). Jakarta: Ufuk Press., 2010.

[24] A. John, Misteri Angka-angka Keramat dalam Hidup Keseharian Kita. Jakarta: Flash Book., 2012.

[25] H. Thalbah, Ensiklopedia mukjizat Al-qur'an dan Hadist. Jakarta: Sapta Sentosa, 2008.

[26] Koentjaraningrat, Pengantar Ilmu Antropologi. Jakarta: Rineka Cipta, 2009.

[27] Amirudin, "Pergeseran Konsep Normatif Judi," Suara Merdeka, 2013.

[28] Sutrisno, Teori-Teori Kebudayaan. Yogyakarta: Kanisius, 2005.

[29] Poerwadarminta, Kamus Besar Bahasa Indonesia. Jakarta. Balai Pustaka, 1995.

[30] Purwaningsih, "Sabung Ayam di Asia Tenggara: Studi Komparatif Indonesia, Malaysia dan Filipina," in Rampak Serantau, Dewan Bahasa dan Pustaka, Brunei Darussalam, 2015.

[31] D. Sugono, Buku Praktis Bahasa Indonesia. Jakarta: Pusat Bahasa., 2003.

[32] Y. Y. Taum, "Dongeng Tujuh Bidadari: Pemetaan Pola Kekerabatan Sastra," in Dalam Prosiding Seminar Nasional Pelestarian Bahasa Ibu (SNBI) XI dan Lokakarya Pelestarian Bahasa Ibu (LPBI) I, Program Studi Magister dan Doktor Linguistik Fakultas Ilmu Budaya Universitas Udayana, Denpasar, 2019. 